\title{
The role of hypoxia in inflammatory disease (Review)
}

\author{
JOHN BIDDLESTONE $^{1,2^{*}}$, DANIEL BANDARRA ${ }^{1 *}$ and SONIA ROCHA ${ }^{1}$ \\ ${ }^{1}$ Centre for Gene Regulation and Expression, College of Life Sciences, University of Dundee, \\ Dundee DD1 5EH; ${ }^{2}$ Plastic Surgery Training Programme, NHS Scotland, Scotland, UK
}

Received January 20, 2015; Accepted January 27, 2015

DOI: 10.3892/ijmm.2015.2079

\begin{abstract}
Mammals have developed evolutionarily conserved programs of transcriptional response to hypoxia and inflammation. These stimuli commonly occur together in vivo and there is significant crosstalk between the transcription factors that are classically understood to respond to either hypoxia or inflammation. This crosstalk can be used to modulate the overall response to environmental stress. Several common disease processes are characterised by aberrant transcriptional programs in response to environmental stress. In this review, we discuss the current understanding of the role of the hypoxia-responsive (hypoxia-inducible factor) and inflammatory (nuclear factor- $\kappa \mathrm{B}$ ) transcription factor families and their crosstalk in rheumatoid arthritis, inflammatory bowel disease and colorectal cancer, with relevance for future therapies for the management of these conditions.
\end{abstract}

\section{Contents}

1. Introduction

2. The HIF system

3. HIF regulation by oxygen

4. HIF target genes

5. Inflammation and the $\mathrm{NF}-\kappa \mathrm{B}$ pathway

6. Crosstalk between hypoxia and inflammation in disease

7. Conclusion

Correspondence to: Dr Sonia Rocha, Centre for Gene Regulation and Expression, College of Life Sciences, University of Dundee, Dow Street, Dundee DD1 5EH, UK

E-mail: s.rocha@dundee.ac.uk

*Contributed equally

Abbreviations: IKK, inhibitor of $\kappa \mathrm{B}$ kinase; NF- $\kappa \mathrm{B}$, nuclear factor- $\mathrm{BB}$; HIF, hypoxia-inducible factor; ARNT, aryl hydrocarbon nuclear translocator; PHD, prolyl hydroxylase; vHL, von Hippel Lindau; TNF, tumour necrosis factor

Key words: hypoxia, inflammation, inflammatory bowel disease, rheumatoid arthritis, colorectal cancer

\section{Introduction}

Oxygen $\left(\mathrm{O}_{2}\right)$ constitutes $20.8 \%$ of the atmospheric air, and is the third-most abundant element in the universe, after hydrogen and helium. It is not only a key component of all major biomolecules of living organisms, but also a key constituent of inorganic compounds. Oxygen homeostasis is crucially important to maintain the survival of all vertebrate species (1). Therefore, organisms developed a way to coordinate the oxygen levels in the intracellular compartments in order to maintain homeostasis. When these mechanisms fail, and the intracellular concentration of oxygen decreases, a stress condition called hypoxia is created. Hypoxia can be defined as a condition lacking the necessary oxygen to meet metabolic requirements. The level at which this is reached will vary depending on the metabolic requirements of the cell. Hypoxia is a relevant physiological stress associated with many processes, such as adaptation to high altitudes or human diseases (e.g, cancer) (2). The hypoxia-inducible factors (HIFs) are a family of transcription factors whose levels are regulated in response to hypoxic stimuli, and when active can enact a transcriptional program that allows the cell to respond to the hypoxic environment.

Another important physiological stress is inflammation. Inflammation represents a protective attempt to eliminate pathogens and initiate the healing process of a wound. As in hypoxia, cells have evolved sophisticated mechanisms to control the inflammatory response to pathogens. A key element of these mechanisms is a family of transcription factors termed nuclear factor $\kappa$-light-chain-enhancer of activated $B$ cells (NF- $\kappa B$ ). NF- $\kappa B$ is composed of several family members that activate signalling pathways in response to a variety of stimuli (such as virus, bacteria or cytokines) which ultimately engage a complex transcriptional program, allowing the cell to respond to this environmental stress (3).

Several diseases, including rheumatoid arthritis (RA), inflammatory bowel disease and colorectal cancer (CRC) result from the deregulation of the hypoxia and inflammation pathways (4-6). Consequently, recent scientific research has been focussed on attempting to understand how these pathways are regulated, crosstalk and respond in disease. In this review, we describe the current understanding of the role of the HIF and NF- $\mathrm{KB}$ transcription factor families in response to hypoxia and inflammation and discuss their crosstalk in $\mathrm{RA}$, inflammatory bowel disease and CRC, with relevance for future therapies for the management of these conditions. 


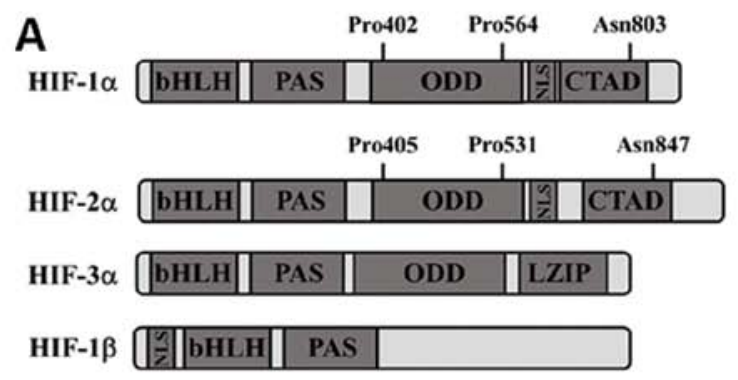

B

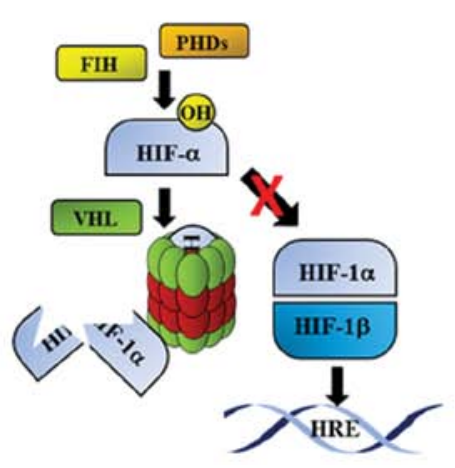

Hypoxia

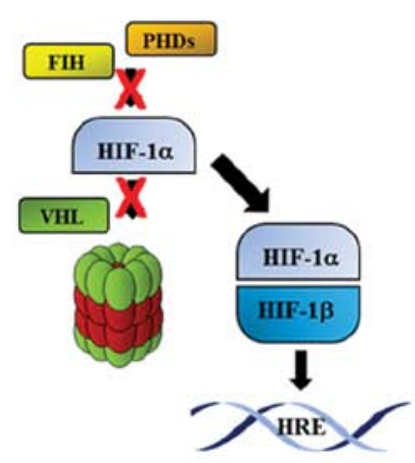

Figure 1. (A) Schematic diagram of HIF proteins. Boxes represent different protein domains. The hydroxylation sites for HIF-1 $\alpha$ and HIF-2 $\alpha$ are noted above the schematic structure. (B) Schematic diagram of HIF pathway. In the presence of oxygen (normoxia), c bind to HIF-1 $\alpha$ and catalyse the hydroxylation of proline residues. Once hydroxylated, HIF-1 $\alpha$ binds rapidly to the vHL, which results in its polyubiquitination. This targets HIF-1 $\alpha$ for proteasome-mediated degradation. In the presence of low oxygen (hypoxia), HIF-1 $\alpha$ is stabilized and can translocate to the nucleus. HIF-1 $\alpha$ dimerises with its partner HIF-1 $\beta$ and transactivates target genes containing hypoxia response elements (HREs). HIF, hypoxia-inducible factor; vHL, von Hippel Lindau; bHLH, basic helix-loop-helix; CTAD, C-terminal transactivation domain; LZIP, leucine zipper; NLS, nuclear localisation signal; ODD, oxygen-dependent domain; PAS, Per/ARNT/Sim domain.

\section{The HIF system}

The HIFs are a family of transcription factors that sense changes in environmental oxygen and orchestrate a transcriptional program, which forms an important part of the cellular response to the hypoxic environment. HIF-1 was first identified over 20 years ago through studies of erythropoietin gene expression (7). HIF is a heterodimeric transcription factor that consists of a constitutively expressed HIF- $1 \beta$ subunit and an $\mathrm{O}_{2}$-regulated HIF- $\alpha$ subunit (8). Three isoforms of HIF- $\alpha$ have been identified since these initial studies (HIF-1 $\alpha,-2 \alpha$ and $-3 \alpha$ ) (Fig. 1A). The HIF- $\alpha$ isoforms are all characterized by the presence of basic helix-loop-helix (bHLH)-Per/ARNT/Sim (PAS) and oxygendependent degradation (ODD) domains (Fig. 1A). Both HIF-1 $\alpha$ and HIF-2 $\alpha$ have important cellular functions as transcription factors with some redundancy in their targets $(9,10)$. HIF-2 $\alpha$ protein shares sequence similarity and functional overlap with HIF-1 $\alpha$, but its distribution is restricted to certain cell types, and in some cases, it mediates distinct biological functions (11). HIF-3 $\alpha$ is the most recently discovered isoform. The regulation of HIF-3 $\alpha$ expression is complex in comparison to HIF-1 $\alpha$ and HIF- $2 \alpha$ with several splice variants that can function as a competitive inhibitors of the HIF- $\alpha$-HIF-1 $\beta$ interaction $(12,13)$, or by directly activating target genes in hypoxia that mediate both hypoxia dependent and independent functions. The role of HIF-3 $\alpha$ in the cellular response to hypoxia remains an active area of study (14). Several splice variants of HIF-1 $\beta$ [also known as aryl hydrocarbon receptor nuclear translocator (ARNT)] have been identified $(15,16)$. Though their exact functions are not known, at least one splice variant has been associated with poor prognosis in oestrogen receptor-negative breast cancer (17).

\section{HIF regulation by oxygen}

The regulation of the HIF- $\alpha$ subunits by oxygen occurs mainly at the post-transcriptional level, and is mediated by hydroxylation-dependent proteasomal degradation (Fig. 1B). In well-oxygenated cells, HIF- $\alpha$ is hydroxylated in its ODD. For
HIF-1 $\alpha$ this is at prolines (Pro)402 and Pro564 (18), whereas HIF-2 $\alpha$ is hydroxylated at Pro405 and Pro531 (Fig. 1B) (19). Proline hydroxylation is catalysed by a class of dioxygenase enzymes called prolyl hydroxylases (PHDs). There are three known PHDs, 1-3, all of which have been shown to hydroxylate HIF-1 $\alpha$. PHD2 has a higher affinity for HIF1 $\alpha$, whereas PHD1 and PHD3 have higher affinity for HIF-2 $\alpha(20,21)$. All PHDs require $\mathrm{Fe}^{2+}$ and $\alpha$-ketoglutarate $(\alpha-\mathrm{KG})$ as co-factors for their catalytic activity and have an absolute requirement for molecular oxygen as a co-substrate, making their activity reduced in hypoxia (22-25).

Prolyl-hydroxylation of HIF- $\alpha$ attracts the von Hippel-Lindau (vHL) tumour suppressor protein, which recruits the Elongin C-Elongin B-Cullin 2-E3-ubiquitin-ligase complex, leading to the Lys48-linked poly-ubiquitination and proteasomal degradation of HIF-1 $\alpha$ (Fig. 1B) (26-28). Interestingly, PHDs have also been shown to be able to sense amino acid availability through $\alpha-K G$ oscillations (29), and the centrosomal protein Cep192 has been described as a hydroxylation target for PHD1 (30), indicating an additional function for these enzymes as nutrient sensors and regulators of cell cycle progression. Both PKM2 and HCLK2 have also both recently been described as new hydroxylation targets for PHD3 $(31,32)$.

In hypoxia the PHDs are inactive, or have reduced activity, since they require molecular oxygen as a cofactor. Under these conditions HIF- $\alpha$ is stabilized, can form a heterodimer with HIF-1 $\beta$ in the nucleus and bind to the consensus cisacting hypoxia response element (HRE) nucleotide sequence 5'-RCGTG-3', which is present within the enhancers and/or promoters of HIF target genes (Fig. 1B) (33-35). HIF- $\alpha$ stabilisation therefore allows the cell to enact a transcriptional programme that is appropriate to the hypoxic environment (18) (Fig. 1B).

\section{HIF target genes}

The HIF heterodimer can regulate the expression of over 100 target genes involved in a broad range of physiological functions including: angiogenesis, erythropoiesis, metabolism, 
A

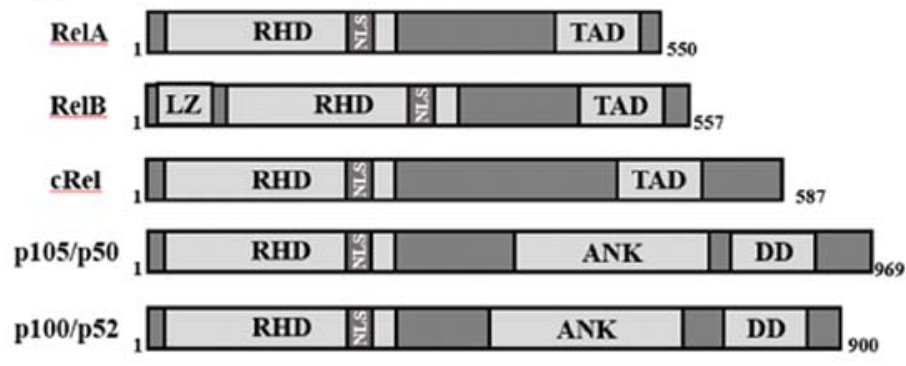

B

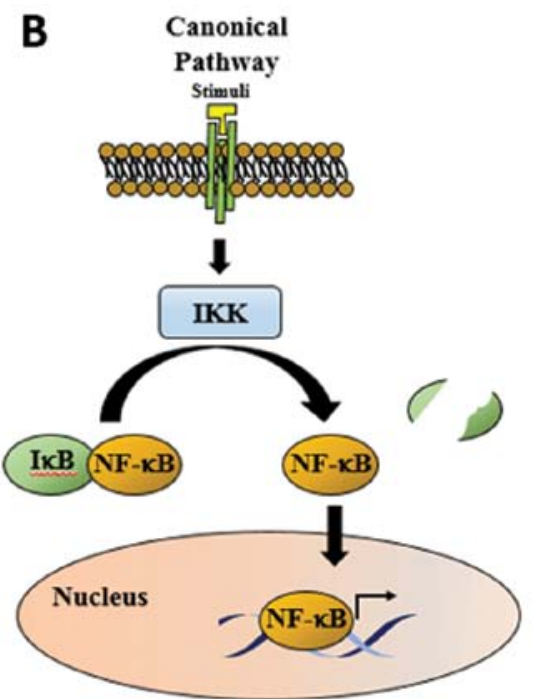

Figure 2. (A) Schematic diagram of NF- $\mathrm{BB}$ subunits. p50 and p52 are not shown, and they are derived from p105 and p100, respectively. Boxes represent different protein domains. (B) NF- $\kappa \mathrm{B}$ canonical pathway. The presence of a stimuli results in the activation of the IKK complex, which mediates the phosphorylation of $\mathrm{I} \kappa \mathrm{B}$ protein, which signals it for proteasomal degradation. This results in NF- $\kappa \mathrm{B}$ dimer release and translocation into the nucleus. NF- $\kappa \mathrm{B}$, nuclear factor- $\kappa \mathrm{B}$; IKK, inhibitor of $\kappa$ B kinase; RHD, Rel homology domain; TAD, C-terminal transactivation domain; LZ, leucine zipper motif; NLS, nuclear localisation signal; ANK, ankyrin-repeat motifs; DD, death domain.

autophagy, apoptosis and other physiological responses to hypoxia (36). Canonical HIF signalling is based on the recognition of a putative HRE in the promoter or enhancer of the target gene that results in the recruitment of the HIF heterodimer and machinery required for transcription. Proteomics approaches have been used to identify protein changes in response to hypoxia in comparison with gene changes. Changes in just over 100 proteins in response to hypoxia have been identified $(37,38)$. However, proteins identified represent both known and undescribed HIF targets, raising the possibility of HIF action outside of the conventional canonical pathway. Indeed, in addition to canonical signalling, there are various described mechanisms by which the stabilised HIF isoforms can influence the activity of other signalling pathways independent of the HIF heterodimer or a HRE. Non-canonical HIF signalling has been demonstrated to regulate aspects of Notch (39), c-Myc (40) and p53 (41) signalling.

\section{Inflammation and the NF-кB pathway}

Inflammation is a complex physiological process characterised by the activation of several coordinated signalling pathways in response to stress. Generally, the inflammatory response involves both anti- and pro-inflammatory mediators, given by the expression of small peptides (e.g., cytokines), glycoproteins (e.g., cluster of differentiation (CD)], and transcription factors, such as $\mathrm{NF}-\kappa \mathrm{B}$.

$\mathrm{NF}-\kappa \mathrm{B}$ is considered the main pro-inflammatory family of transcription factors (42-44). In mammalians, it is characterised as a family of five Rel-domain proteins; RelA, RelB, cRel, p100/p52 and p105/p50 (Fig. 2A). Interestingly, it has been shown that almost all combinations of homo- or hetero-dimers between the five NF- $\kappa \mathrm{B}$ subunits are possible (45). This is important, not only because it gives an extra layer of complexity to the NF- $\mathrm{NB}$ system, but also because it gives specificity according to cellular context, stimuli or DNA sequences that are bound to the subunits $(44,46)$. All the NF- $\kappa \mathrm{B}$ subunits are characterised by a conserved 300-amino acid domain, the Rel homology domain (RHD), which is located in the N-terminus of the protein (Fig. 2A), and is responsible for dimerisation, and DNA binding. While RelA, RelB and cRel contain a C-terminal transactivation domain (TAD) (Fig. 2A), p105 and p100 contain Ankyrin-repeats motifs in their C-terminus (ANK) (Fig. 2A), responsible for the dimerisation with other subunits, and subsequent sequestration/inactivation in the cytoplasm (Fig. 2B).

There are distinct pathways for the activation of $N F-\kappa B$, according to the stimulus, as well as the kinases and $\mathrm{NF}-\kappa \mathrm{B}$ subunits involved (3). The most common, and most well studied is the classical or canonical NF- $\kappa$ B pathway (Fig. 2B). In unstimulated cells, the NF- $\kappa \mathrm{B}$ dimers remain inactive in the cytosol,

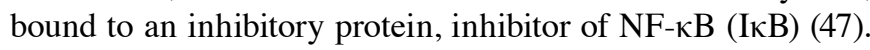
Upon stimulation, for example by the pro-inflammatory cytokine, tumour necrosis factor- $\alpha$ (TNF- $\alpha$ ), the inhibitor of $\kappa B$ kinase (I $\mathrm{B}$ kinase; IKK), is activated, and phosphorylates I $\mathrm{B}$. This leads to the degradation of I $\mathrm{B}$ and the release/translocation of the NF- $\kappa \mathrm{B}$ complex into the nucleus (48). In the nucleus, the activated NF- $\kappa \mathrm{B}$ complex binds to specific 9-10 base pair DNA sequences ( $\kappa \mathrm{B}$ sites) to activate a complex regulatory network in response to a specific stimulus (49). The combination of different possible homo- and heterodimers, stimuli and cellular context leads to a myriad of possible outcomes, namely the activation or inhibition of apoptosis, cellular growth and carcinogenesis (50).

The NF- $\kappa \mathrm{B}$ system is complex and is involved in multiple biological roles; it is thus expected that it is deregulated in many different diseases. NF- $\kappa \mathrm{B}$ abnormal activation has been associated with several human diseases, such as inflammationrelated diseases (inflammatory bowel disease and asthma), cancer (apoptosis suppression), viral infections (HIV) and genetic diseases (incontinentia pigmenti) (51). 


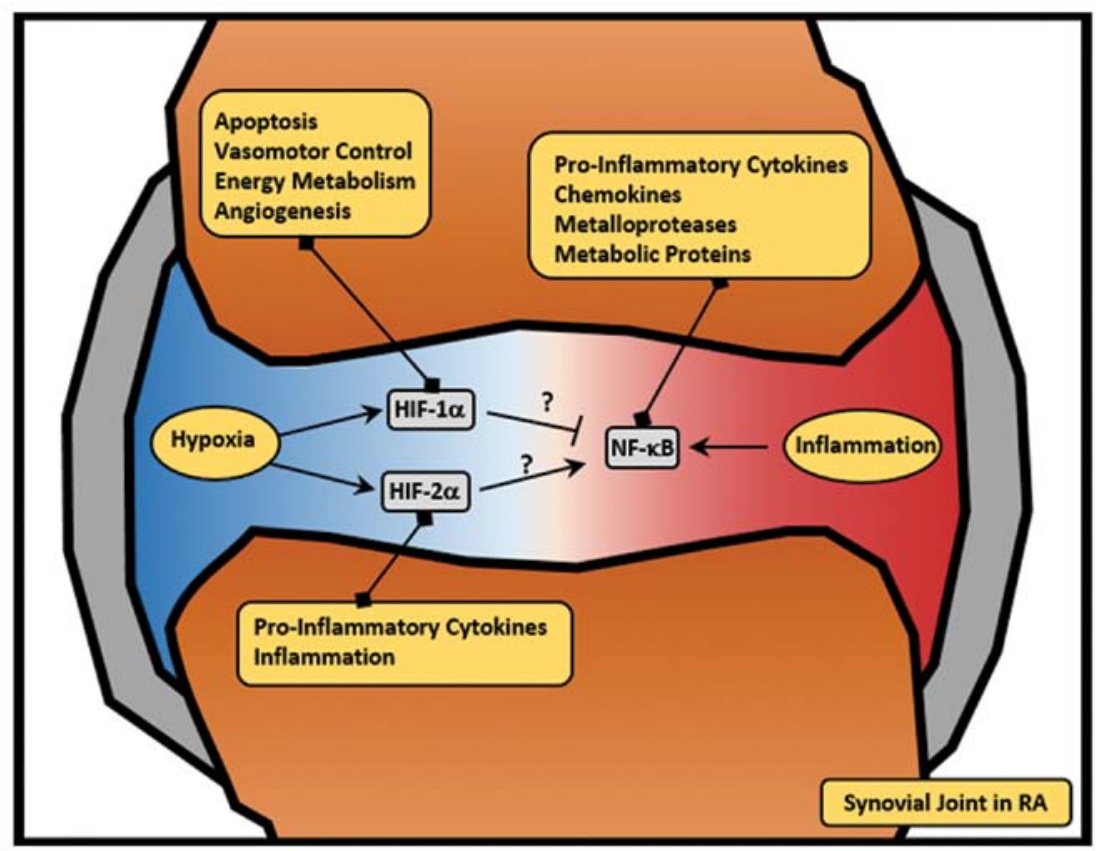

Figure 3. HIF and NF-kB crosstalk in RA. In RA, the synovial join is characterised by hypoxic and inflammatory regions (in blue and red, respectively). Hypoxia leads to the activation of HIF-1 $\alpha$, which is involved in several cellular processes (such as apoptosis, vasomotor control, energy metabolism and angiogenesis). Additionally, hypoxia leads to the activation of HIF-2 $\alpha$, which is involved in the activation of pro-inflammatory cytokines. In RA, inflammation leads to the activation of NF- $\mathrm{KB}$, which activates a pro-inflammatory programme, including pro-inflammatory cytokines, chemokines, metalloproteases and metabolic proteins. While HIF-1 $\alpha$ has been implicated in the repression of the NF-KB pathway (59), HIF-2 $\alpha$ has been shown to increase inflammation (78). In RA, this

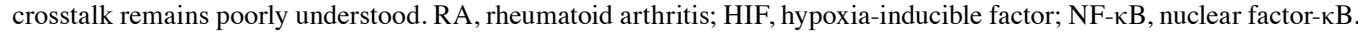

\section{Crosstalk between hypoxia and inflammation in disease}

Hypoxia and inflammation are intimately linked. It has been reported that individuals with mountain sickness presented with increased inflammatory cytokines circulating in the blood (52). Additionally, healthy volunteers who have been exposed to a hypoxic environment for three nights in high altitudes ( $>3,400$ meters), presented with high levels of the inflammatory cytokine, interleukin (IL)-6, in the blood (53). On the other hand, several inflammatory diseases, such as RA and inflammatory bowel disease, also exhibit areas of combined hypoxia and inflammation, which are usually associated with a poor prognosis of the disease (54-57).

Hypoxia and inflammation are also connected at the molecular level $(48,58,59)$. HIF (hypoxia) and NF- $\mathrm{kB}$ (inflammation) have been shown to have several common target genes, common regulators, and importantly, common stimuli (48). $N F-\kappa B$ activation has been shown to stabilise HIF- $1 \alpha$ in hypoxia, and, together with HIF-1 $\beta$, in inflammation $(60,61)$. On the other hand, HIF-1 $\alpha$ has been shown to repress NF- $\mathrm{kB}$ in vivo and in vitro under inflammatory conditions $(59,62,63)$. The complexity of the combined response of HIF and NF- $\mathrm{kB}$ in hypoxia makes the crosstalk of these two pathways more intricate, and difficult to study. However, by developing a suitable inflammatory model, where the pathways can be controlled, as well as the conditions of the stimuli, these studies could provide very useful information that ultimately should be used to uncover new therapeutic strategies in a diverse range of diseases where hypoxia and inflammation are predominant features. In this review, the crosstalk between the main players induced in both inflammation and hypoxia in three clinical settings is addressed.
Hypoxia and inflammation crosstalk in RA. RA is a systemic autoimmune disorder characterised by chronic inflammation of the synovial membranes of joint tissues at multiple anatomical sites which ultimately leads to localised destruction and debilitating deformity $(64,65)$. The RA joint synovium is characterised by both inflammatory and hypoxic regions (Fig. 3), which are highly infiltrated with lymphocytes $\left(\mathrm{CD}^{+} \mathrm{T}\right.$ cells, and B cells), macrophages and macrophage-like and fibroblastlike synoviocytes (66). The molecular basis of RA is still poorly understood, mainly because RA is a heterogeneous disease composed of several possible treatment responses, and clinical manifestations (67-69). These differences make RA difficult to treat, and further studies on the crosstalk between pathways involved in the disease are required.

The role of $N F-\kappa B$ in $R A$. The deregulation of several transcription factors, such as NF- $\kappa \mathrm{B}$, activator protein-1 (AP-1), and signal transducer and activator of transcription (STATs), has been strongly associated with the inflammatory setting of RA (70-72). NF- $\mathrm{BB}$, in particular, has been shown to be highly activated in the RA synovium $(73,74)$. This is exceptionally important due to the major role of NF- $\mathrm{kB}$ in activating inflammatory responses, such as through the activation of the pro-inflammatory cytokine, TNF- $\alpha$, or the chemokine, IL-8 (75). The activation of a coordinated and complex network of pro-inflammatory cytokines, chemokines, metalloproteases (MPPs) and metabolic proteins by NF- $\mathrm{KB}$, leads to the activation of a positive feedback loop, enhancing the activation of more pro-inflammatory signals that ultimately results in chronic and persistent inflammation (Fig. 3) (75,76).

The role of HIF in RA. The HIF family of proteins are additional transcription factors with direct relevance to RA (77,78). Recently, HIF-1 $\alpha$ was identified as a key player in 


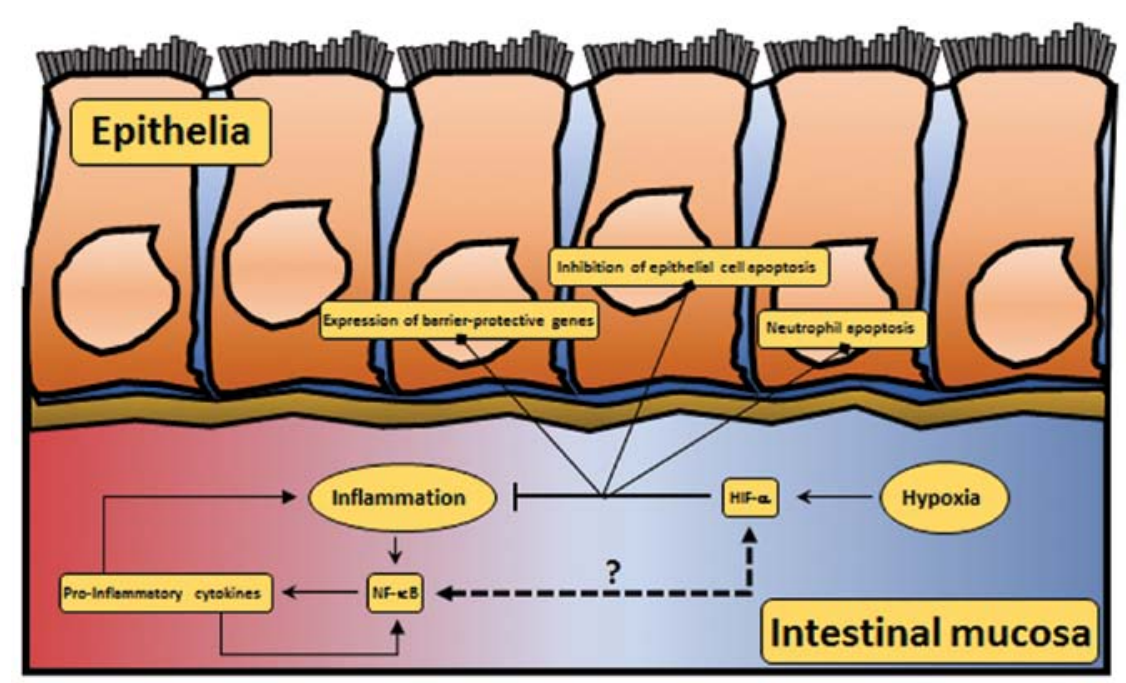

Figure 4. HIF and NF- $\mathrm{NB}$ crosstalk in inflammatory bowel disease. In IBD, the intestinal mucosa is characterised by hypoxic and inflammatory regions (in blue and red, respectively). HIF-1 $\alpha$ is activated in hypoxia, and acts as a protective barrier by inhibiting apoptosis of epithelial cells, enhancing the barrier-protective genes, and by promoting the apoptosis in neutrophils. Inflammation leads to the activation of NF- $\mathrm{B}$, which is involved in the expression of inflammatory cytokines that can lead to inflammation and/or NF- $\kappa$ B activation. HIF, hypoxia-inducible factor; NF- $\kappa \mathrm{B}$, nuclear factor- $\kappa \mathrm{B}$; IBD, inflammatory bowel disease.

RA, and therefore as a potential therapeutic target (79). HIF is important to coordinate the hypoxia response in the synovial tissue, and the deregulation or failure of that response leads to cellular dysfunction, and can ultimately lead to cell death (80). Furthermore, the intense hypoxic region in the synovial tissue (2-4\%), activates a hypoxic response through HIF, which is involved in regulating several genes involved in apoptosis, vasomotor control, energy metabolism, and importantly, angiogenesis (Fig. 3) (16,48,81-83).

Even though the role of HIF in RA has been firmly established, the contribution of each $\alpha$-subunit remains poorly understood. Recently, HIF-2 $\alpha$ was implicated as the essential catabolic regulator of inflammation in RA (78). In that study, the authors demonstrated that the overexpression of HIF- $2 \alpha$ in joint tissues, but not HIF-1 $\alpha$, was sufficient to induce RA pathogenesis (78). The full contribution of the $\alpha$-subunits to RA remains elusive. However, it seems clear that each $\alpha$-subunit contributes differently to the progression of RA. HIF-1 $\alpha$ plays a more anti-inflammatory role, whereas HIF- $2 \alpha$ acts in a pro-inflammatory manner. What regulates this differential expression of the isoforms is still unknown. However, taking into consideration that $\mathrm{NF}-\kappa \mathrm{B}$ is the main activator of the HIF transcription factors, it would be interesting to understand whether NF- $\kappa \mathrm{B}$ has any role in this HIF-1 $\alpha$ to HIF- $2 \alpha$ switch, and whether that would be dependent of the presence of hypoxia, inflammation, or both combined.

Inflammatory bowel disease (IBD). The intestinal mucosa is exposed to steep hypoxic gradients (63) and is in a constant state of controlled inflammation, which is necessary to allow tolerance to otherwise harmless ingested dietary antigens (Fig. 4) (84). This fine balance is pathologically disturbed in inflammatory bowel disease (IBD); a relapsing-remitting progressive disorder of the gastrointestinal tract that comprises both Crohn's and ulcerative colitis. The symptoms of IBD can range from mild to severe and include abdominal pain, intestinal bleeding, weight loss, fever and diarrhoea (85). The two
IBD sub-types have different distribution patterns: ulcerative colitis is restricted to the colon, whereas Crohn's colitis can affect any part of the GI tract. Both are thought to occur when inappropriate immunological activity in the intestinal mucosa results in epithelial barrier dysfunction leading to exposure of the mucosal immune system to luminal antigenic material and further cycles of inflammation and barrier dysfunction that underlie disease progression $(86,87)$.

Role of the HIF system in IBD. Hypoxia has been found to play a role in IBD. Lower resting oxygen levels have been demonstrated in sections of IBD tissue compared to the controls using a 2-nitroimidazole based approach (63). In keeping with these observations, HIF- $1 \alpha$ and HIF- $2 \alpha$ activation has been associated with disease and increased vascular density in human specimens (88). The increased vascular density was subsequently demonstrated to be effected by vascular endothelial growth factor (VEGF), an established target of the HIF system (89). Compartmental analyses of the effects of hypoxia have been possible in murine models, where hypoxia has been shown to affect the epithelium, primarily during periods of inflammation (63). The colonic epithelium is the most hypoxic and HIF-active tissue layer because it is physically farthest away from the colonic vascular plexus and closest to the anoxic bowel lumen. This effect is exacerbated by oxygen consumption by luminal bacteria (90), and the presence of inflammatory mediators and lipopolysaccharide (LPS), which have been shown to regulate HIF activity (48).

In the context of IBD, HIF system activity is thought to be protective, acting through three mechanisms: i) inhibition of epithelial cell apoptosis; ii) enhanced expression of barrier-protective genes; and the iii) promotion of neutrophil apoptosis (Fig. 4) (86). Evidence of the anti-apoptotic effects of HIF has been demonstrated indirectly through experiments to investigate the role of the hydroxylase inhibitor, dimethyloxaloylglycine (DMOG), in colitis. Using a murine model of dextran sodium sulfate (DSS)-induced colitis, HIF stabilisation following treatment with DMOG has been shown to prevent 
apoptosis in a mechanism thought to be mediated by the antiapoptotic protein, cIAP-2 (91). Recently, this effect has been specifically attributed to PHD1, since the homozygous loss of PHD1, but not PHD2 or PHD3, has been shown to be protective in the same murine model of DSS-induced colitis (92). This effect is most likely HIF-dependent, since the conditional knockout of HIF-1 $\alpha$ in mouse intestinal epithelial cells has been shown to result in an enhanced susceptibility to the development of colitis (63).

In addition to its anti-apoptotic effects, the HIF system can protect against colitis through the expression of barrierprotective genes. Several HIF-dependent target genes have been proposed as mediators of this effect: CD55 (93), ecto-50 nucleotidase (94), A2B receptor (95) MUC-3 (96), intestinal trefoil factor (97), and P-glycoprotein (98) all play a role in the regulation of the intestinal mucosa barrier and have all been demonstrated to be regulated in a hypoxia-dependent manner.

There is also evidence of the differential effects of the HIF- $\alpha$ isoform in IBD. HIF-2 $\alpha$ expression has been shown to be increased in colon tissues of mice after the induction of colitis. This was also observed in patients with ulcerative colitis or Crohn's disease (62). Interestingly, in that study, while the loss of HIF- $2 \alpha$ was associated with attenuated colonic inflammation, the overexpression of HIF-2 $\alpha$ led to spontaneous colitis and increased inflammation.

Role of $N F-\kappa B$ in IBD. Other transcriptional programs are active in IBD in addition to those enacted by the HIF system. IBD is primarily an inflammatory pathology and $N F-\kappa B$ activity has been linked to its progression (5). A high degree of $\mathrm{NF}-\kappa \mathrm{B}$ induction has been demonstrated in intestinal macrophages and epithelial cells (99). In IBD, inflammatory cytokines can drive NF- $\kappa \mathrm{B}$ activation, leading to the production of more inflammatory cytokines and potentiating further $\mathrm{NF}-\kappa \mathrm{B}$ activation (Fig. 4). NF- $\kappa \mathrm{B}$-induced TNF- $\alpha$ expression is one example of this type of positive feedback loop (100). Interestingly, $\mathrm{NF}-\kappa \mathrm{B}$ can have a dual role in IBD, potentiating inflammation in intestinal macrophages while protecting from inflammation in mucosal epithelial cells. Sharing interesting similarities to the effects of HIF activation, NF- $\kappa \mathrm{B}$ signalling in intestinal epithelial cells has been shown to be protective against the development of colitis (101). Deletion of the NF- $\mathrm{BB}$ pathway in intestinal epithelial cells results in decreased expression of anti-apoptotic genes, such as Bcl-xL, and leads to reduced epithelial barrier function and increased susceptibility to colitis (102). Conditional knockout of NEMO and subsequent $\mathrm{NF}-\kappa \mathrm{B}$ inhibition has been shown to result in severe epithelial inflammation in a murine model (102). Similarly, epithelial cell-specific IKK $\beta$ deletion has been shown to result in the sustained production of pro-inflammatory Th1 cytokines and increased intestinal inflammation (103). Several treatments have been proposed to target $N F-\kappa B$ activity in IBD, including proteasome blockade, the administration of non-coding RNAs to interfere with NF- $\kappa$ B-DNA binding and anti-TNF- $\alpha$ immunotherapy. However, all have been met with significant systemic toxicity due to the broad role of NF- $\mathrm{NB}$ in multiple organs.

$N F-\kappa B-H I F$ crosstalk in IBD. Sharing similarities with the microenvironment of RA, in IBD both inflammation and hypoxia are present in the intestinal epithelium and contribute to disease progression (104). It is generally [but not universally (105)] understood that both NF- $\kappa \mathrm{B}$ and HIF activity are protective in episodes of colitis (101). Significant crosstalk between these pathways has already been established, and it has been proposed that both pathways may act in concert to contribute to the epithelial barrier function of the colon in a process that is deregulated in IBD.

One example of this crosstalk is the regulation of apoptosis by both pathways $(106,107)$. The caspase recruitment domain family, member 9 (CARD9) is understood to function as a molecular scaffold for the assembly of a BCL10 signalling complex that activates $\mathrm{NF}-\kappa \mathrm{B}$ (106), and has also been shown to be involved in the regulation of hypoxia-sensitive pathways (107). CARD9 therefore represents one point of crosstalk that may be important in the development of IBD as a promising target for further investigation.

Our laboratory and others have demonstrated NF- $\kappa \mathrm{B}-$ dependent HIF-1 $\alpha$ mRNA regulation $(61,108)$. NF- $\kappa$ B can also regulate HIF signalling through IKK $\gamma$ and HIF- $2 \alpha$, which increases HIF- $2 \alpha$ transcriptional activity through interaction with cAMP response element-binding (CREB) binding protein (CBP)/p300 (109). Negative feedback through the NF- $\mathrm{B}$ dependent induction of the micro-RNA, $m i R-155$, in response to LPS has been shown to target HIF-1 $\alpha$ for silencing (110). Furthermore, our laboratory have recently demonstrated an evolutionarily conserved negative feedback mechanism through which $\mathrm{HIF}$ can regulate $\mathrm{NF}-\kappa \mathrm{B}$ in a mechanism that is dependent on the kinases, TAK-IKK and CDK6 (59).

CRC. CRC is a lethal disease affecting over 500,000 individuals annually (111). In contrast to the protective effects of HIF and $\mathrm{NF}-\kappa \mathrm{B}$ activity in IBD, both can play important roles in the development of colorectal malignancy. In CRC, the hypoxic milieu is similar to that of IBD but, critically, the cells are transformed to allow them to react differently to the activation of either system. In addition, chronic inflammation is a hallmark of cancer (112). The role of the HIF system and the role of NF- $\kappa$ B activity are considered below, and the significance of their crosstalk with respect to the development of CRC is examined.

Role of the HIF system in CRC. The role of the HIFs in cancer progression has long been appreciated due to their ability to promote angiogenesis through one of the principally identified HIF-1 $\alpha$ target genes, VEGFA (113). However, it is becoming more evident that hypoxia and the HIF system can affect tumour growth through modulation of proliferation, apoptosis and epithelial to mesenchymal transition (EMT) (Fig. 5). Hypoxia and the subsequent HIF activation are generally understood to be prognostically bad and lead to tumour progression (114). In CRC, HIF-1 $\alpha$ stabilisation has been shown to lead to a poor disease outcome. Shay et al (114) demonstrated that the inhibition of HIF signalling using acriflavine halted the progression of an autochthonous model of established colitis-associated colon cancer in immuno-competent mice. In their model, treatment with acriflavine was shown to decrease tumour number, size and advancement, in an effect thought to be mediated through the inhibition of HIF-dependent targets, such as VEGFA. These data provide a direct link between HIF-1 $\alpha$ expression and tumour progression. However, HIF isoform activation can be antagonistic in the context of tumour progression. In contrast to the effect of high HIF-1 $\alpha$ expression, high HIF-2 $\alpha$ expression has recently been reported to prevent CRC progression (115). The antagonistic effects of HIF- $1 \alpha$ and HIF- $2 \alpha$ are important 


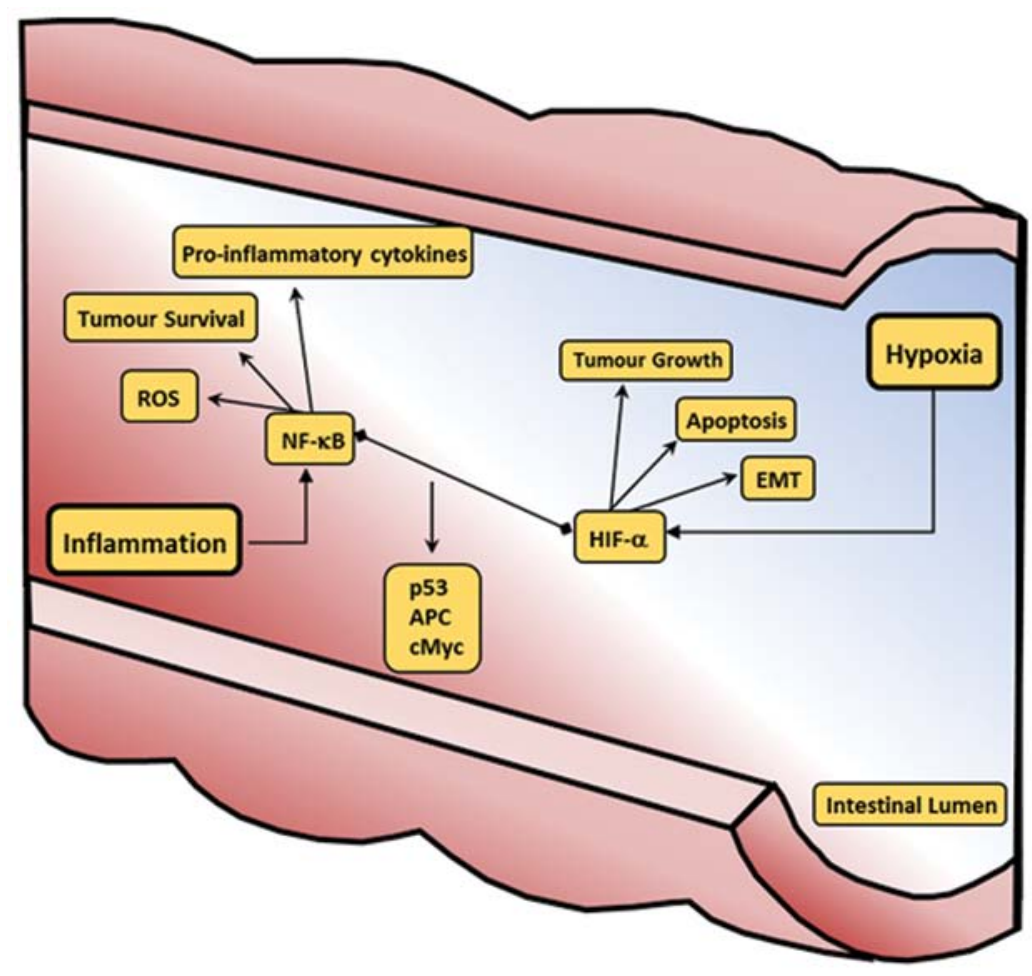

Figure 5. HIF and NF- $\mathrm{KB}$ crosstalk in CRC. In CRC, the intestinal lumen is characterised by hypoxic and inflammatory regions (in blue and red, respectively). HIF-1 $\alpha$ is activated in hypoxia, and is involved in the modulation of tumour growth, apoptosis, and EMT. Inflammation leads to the activation of NF- $\mathrm{KB}$, which is involved in the expression of pro-inflammatory cytokines, ROS production, and tumour survival. In CRC, there are some points of crosstalk between NF- $\mathrm{KB}$

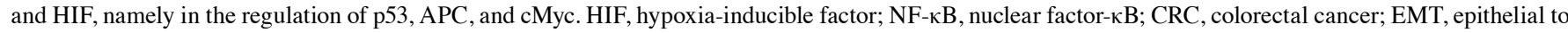
mesenchymal transition; ROS, reactive oxygen species; APC, adenomatous polyposis coli.

for the regulation of proliferation and apoptosis in cancer biology $(40,82,116)$. The HIF system can affect proliferation through the regulation of cMyc. HIF-1 $\alpha$ can promote cell cycle arrest by the direct opposition of c-Myc activity and the induction of p21 in CRC (116). Conversely, HIF-2 $\alpha$ has been shown to promote proliferation in through its augmentation of $\mathrm{cMyc}$ function (40).

The HIF system can also affect apoptosis through the regulation of p53. p53 stability leads to apoptosis in somatic cells and it is frequently mutated in cancers in pursuit of immortality. HIF-1 $\alpha$ has been shown to stabilise wild-type $p 53$ via physical interaction through its ODD $(41,117)$. As a form of negative feedback, p53 can promote the degradation of HIF-1 $\alpha$ (118). The negative feedback of wild-type p53 on HIF-1 $\alpha$ could explain the increased stability of HIF-1 $\alpha$ in tumours that express mutant p53 which is incapable of degrading HIF-1 $\alpha$. The net result of the p53-HIF-1 $\alpha$ interaction is increased apoptosis in damaged cells that are exposed to hypoxia (119). HIF-2 $\alpha$ can inhibit p53 phosphorylation, resulting in a reduction in 553 pathway activity and the prevention of apoptosis in response to damaging stimuli (120). In addition to its role in the regulation of $\mathrm{p} 53$, HIF has been linked to the positive regulation of apoptosis through the control of several pro-apoptotic factors, including caspase-3, Fas and Fas ligand (121).

Hypoxia is a critical determinant of the motile and invasive phenotype of cancer cells. HIF activation is also important in the regulation of genes involved in EMT, including the direct regulation of the EMT-promoting transcription factors, Snail and Twist, which have both been described as direct targets of the HIF system (122-124). EMT is a critical event in the induc- tion of tumour metastasis (125). Notch has also been shown to mediate HIF-1 $\alpha$-dependent EMT (126).

Role of $N F-\kappa B$ in $C R C$. The role of $N F-\kappa B$ in $\mathrm{CRC}$ is an active area of study (101,127-129). Inflammation is an important trigger in the establishment and development of CRC. Patients with long-standing IBD have an increased risk of developing CRC $(127,128)$. In this context, NF- $\kappa \mathrm{B}$ activation can promote tumourigenesis and CRC progression. In CRC, chronic inflammation results in sustained reactive oxygen species (ROS) production, leading to DNA damage (Fig. 5) (130). Treatment with non-steroidal anti-inflammatory drugs (NSAIDs) reduces the development of CRC in patients with IBD and hereditary $\mathrm{CRC}(131,132)$, and the inactivation of $\mathrm{NF}-\kappa \mathrm{B}$ signalling reduces the formation of inflammation-associated tumours $(101,129)$. IL-6 has been shown to be important for the number and size of tumours formed in mice (133), and IKK $\beta$ conditional knockout mice have been shown to develop more numerous tumours (134).

As with the HIF system, the mechanism of NF- $\kappa \mathrm{B}$-induced tumourigenesis and progression can be multifactorial. The activation of the NF- $\mathrm{B}$ pathway confers survival, proliferation, angiogenic and migratory advantages (Fig. 5) (112,135-138); all of which are hallmarks of cancer (112). NF- $\kappa \mathrm{B}$ activation can block apoptosis by regulating the anti-apoptosis proteins, such as inhibitor of apoptotic proteins (IAPs) (139), or by the inhibition of prolonged c-Jun N-terminal kinase (JNK) signalling, modulating the accumulation of ROS (140). Alternatively, $\mathrm{NF}-\kappa \mathrm{B}$ activation can enhance IL-2 production, which can activate Janus kinase 3 (Jak3) by autophosphorylation (141). Jak3 can activate STAT3. Jak3 and STAT3 over-activation has been observed in human colon cancer in vivo and in vitro, and 
shown to prevent apoptosis, leading to poor prognosis $(142,143)$. In addition, $\mathrm{NF}-\kappa \mathrm{B}$ activation can affect proliferation and cell growth through the regulation of its target genes, cyclin D1 and cMyc (144-146), and promote angiogenesis through the regulation of VEGF and IL-8 (136). Finally, NF- $\kappa$ B activation has been shown to affect the expression of matrix metalloprotease-9 (MMP-9), in murine colon adenocarcinoma cells (147), an important protein in the regulation of migration and invasion.

$N F-\kappa B-H I F$ crosstalk in $C R C$. The data presented above demonstrate a clear overlap between the effectors of the HIF and $\mathrm{NF}-\kappa \mathrm{B}$ systems in the establishment and development of CRC. Solid tumours are characterised by the presence of hypoxia, as well as inflammation (6). Potential points for crosstalk include the regulation of cMyc and p53 (Fig. 5). NF- $\kappa \mathrm{B}$ interacts with the co-activators, p300 and CREB-binding protein, to inhibit p53 function. This effect is reinforced by the $\mathrm{NF}-\kappa \mathrm{B}$-dependent upregulation of the p53 inhibitor, mouse double minute 2 (MDM2) $(3,148)$ and is similar to that exerted on $\mathrm{p} 53$ by HIF-1 $\alpha$. The expression of NF- $\kappa \mathrm{B}, \mathrm{HIF}, \mathrm{VEGF}$ and $\mathrm{Bcl}-3$ has been shown to correlate with proliferation, angiogenesis, decreased survival and a poor clinical outcome $(149,150)$. In addition, TNF- $\alpha$ has been shown to stabilise Snail and $\beta$-catenin in a process that requires the downregulation of glycogen synthase kinase $-3 \beta$ (GSK $3 \beta$ ) by $N F-\kappa B$ and the activation of Akt cascades, resulting in the promotion of EMT (151). These data are clinically important since NF- $\mathrm{BB}$ and Twist have been associated with lymph node metastasis in patients with CRC (152). Interestingly, HIF has been shown to interact with both Snail and Twist, making this another potential point for crosstalk between the pathways (153).

In addition to the mechanisms outlined above, there is a complex interplay between $\mathrm{HIF}, \mathrm{NF}-\kappa \mathrm{B}$ and adenomatous polyposis coli (APC), that appears to be important in CRC (Fig. 5). One of the earliest events in the development of CRC is loss of the APC gene. Our laboratory has recently reported a functional crosstalk between HIF-1 $\alpha$ and APC at the transcriptional level (154). HIF activation represses APC expression, acting at its promoter to result in positive activation and proliferation through the $\mathrm{Wnt} / \beta$-catenin signalling and the TCF-LEF pathway (155), reduction in genetic and microtubule stability and reductions in cell migration $(6,156)$.

The repression of APC by HIF-1 $\alpha$ is complicated by the fact that medium levels of $\beta$-catenin can induce $N F-\kappa B$, resulting in positive feedback, and high levels of $\beta$-catenin inhibit $\mathrm{NF}-\kappa \mathrm{B}$, resulting in negative feedback (6). Further studies are required to determine the functional significance of this interaction in vivo. However, it represents another exciting point of crosstalk with importance for CRC disease progression.

\section{Conclusion}

In this review, the current understanding of the mechanisms of the HIF and NF- $\kappa \mathrm{B}$ systems has been discussed with specific reference to the crosstalk between these two stress-responsive pathways. This crosstalk is significant for many disease processes and its role in RA, inflammatory bowel disease and $\mathrm{CRC}$ has been discussed in detail. It is important to note that the crosstalk between these pathways has significance beyond pathological processes. For example, in healthy individuals who live at a high altitude, prolonged HIF activation can lead to reduced NF- $\kappa \mathrm{B}$ activity, effectively dampening the immune response. Further studies in this area is required; however, it is interesting that the anecdotal evidence of increased $H$. pylor $i$ infection in Tibetan monks exists (157). Individuals with mountain sickness have presented with increased levels of inflammatory cytokines circulating in the blood (52). Another study demonstrated that healthy volunteers who spent three nights at high altitudes ( $>3,400$ meters), presented with high levels of the inflammatory cytokine, IL-6 (53). This hypoxiainflammation crosstalk is also relevant in the clinical context. It was shown that ischemia in organ grafts increased the risk of inflammation and, consequently, graft failure or organ rejection (158). Accurate systematic experimentation is important to determine the mechanisms of the crosstalk between these pathways since these findings may have an impact on multiple disease processes, apart from those discussed herein. These include diabetes and systemic sclerosis, where limb perfusion is not optimal, resulting in increased tissue breakdown in the absence of an appropriate inflammatory response, leading to an increased infection rate.

\section{Acknowledgements}

We would like to thank members of the S.R. laboratory for their helpful discussions. J.B. is a CR-UK clinical fellow, D.B. is funded by a Wellcome Trust ISSF award, the S.R. laboratory is funded by a CR-UK Senior Research Fellowship (C99667/A12918). This study was also supported by a Wellcome Trust Strategic Award (097945/B/11/Z).

\section{References}

1. Semenza GL: Regulation of oxygen homeostasis by hypoxiainducible factor 1. Physiology (Bethesda) 24: 97-106, 2009.

2. Semenza GL: HIF-1 and human disease: One highly involved factor. Genes Dev 14: 1983-1991, 2000.

3 . Perkins ND: The diverse and complex roles of NF- $\kappa B$ subunits in cancer. Nat Rev Cancer 12: 121-132, 2012.

4. Thornton RD, Lane P, Borghaei RC, Pease EA, Caro J and Mochan E: Interleukin 1 induces hypoxia-inducible factor 1 in human gingival and synovial fibroblasts. Biochem J 350: 307-312, 2000.

5. Taylor CT: Interdependent roles for hypoxia inducible factor and nuclear factor-kappaB in hypoxic inflammation. J Physiol 586: 4055-4059, 2008.

6. Näthke I and Rocha S: Antagonistic crosstalk between APC and HIF-1 $\alpha$. Cell Cycle 10: 1545-1547, 2011

7. Semenza GL and Wang GL: A nuclear factor induced by hypoxia via de novo protein synthesis binds to the human erythropoietin gene enhancer at a site required for transcriptional activation. Mol Cell Biol 12: 5447-5454, 1992.

8. Wang GL, Jiang BH, Rue EA and Semenza GL: Hypoxiainducible factor 1 is a basic-helix-loop-helix-PAS heterodimer regulated by cellular $\mathrm{O}_{2}$ tension. Proc Natl Acad Sci USA 92: 5510-5514, 1995.

9. Carroll VA and Ashcroft M: Role of hypoxia-inducible factor (HIF)-1alpha versus HIF-2alpha in the regulation of HIF target genes in response to hypoxia, insulin-like growth factor-I, or loss of von Hippel-Lindau function: Implications for targeting the HIF pathway. Cancer Res 66: 6264-6270, 2006.

10. Zhou J, Schmid T, Schnitzer S and Brüne B: Tumor hypoxia and cancer progression. Cancer Lett 237: 10-21, 2006.

11. Patel SA and Simon MC: Biology of hypoxia-inducible factor-2alpha in development and disease. Cell Death Differ 15: 628-634, 2008

12. Makino Y, Cao R, Svensson K, Bertilsson G, Asman M, Tanaka H, Cao Y, Berkenstam A and Poellinger L: Inhibitory PAS domain protein is a negative regulator of hypoxia-inducible gene expression. Nature 414: 550-554, 2001. 
13. Yamashita T, Ohneda O, Nagano M, et al: Abnormal heart development and lung remodeling in mice lacking the hypoxiainducible factor-related basic helix-loop-helix PAS protein NEPAS. Mol Cell Biol 28: 1285-1297, 2008.

14. Zhang P, Yao Q, Lu L, Li Y, Chen PJ and Duan C: Hypoxiainducible factor 3 is an oxygen-dependent transcription activator and regulates a distinct transcriptional response to hypoxia. Cell Rep 6: 1110-1121, 2014.

15. Bárdos JI and Ashcroft M: Negative and positive regulation of HIF-1: A complex network. Biochim Biophys Acta 1755: 107-120, 2005.

16. Rocha S: Gene regulation under low oxygen: Holding your breath for transcription. Trends Biochem Sci 32: 389-397, 2007.

17. Qin C, Wilson C, Blancher C, Taylor M, Safe S and Harris AL: Association of ARNT splice variants with estrogen receptornegative breast cancer, poor induction of vascular endothelial growth factor under hypoxia, and poor prognosis. Clin Cancer Res 7: 818-823, 2001.

18. Kaelin WG Jr and Ratcliffe PJ: Oxygen sensing by metazoans: The central role of the HIF hydroxylase pathway. Mol Cell 30: 393-402, 2008

19. Haase VH: Renal cancer: Oxygen meets metabolism. Exp Cell Res 318: 1057-1067, 2012.

20. Berra E, Benizri E, Ginouvès A, Volmat V, Roux D and Pouysségur J: HIF prolyl-hydroxylase 2 is the key oxygen sensor setting low steady-state levels of HIF-1alpha in normoxia. EMBO J 22: 4082-4090, 2003

21. Appelhoff RJ, Tian YM, Raval RR, Turley H, Harris AL, Pugh CW, Ratcliffe PJ and Gleadle JM: Differential function of the prolyl hydroxylases PHD1, PHD2, and PHD3 in the regulation of hypoxia-inducible factor. J Biol Chem 279: 38458-38465 2004.

22. Epstein AC, Gleadle JM, McNeill LA, et al: C. elegans EGL-9 and mammalian homologs define a family of dioxygenases that regulate HIF by prolyl hydroxylation. Cell 107: 43-54, 2001.

23. Fandrey J, Gorr TA and Gassmann M: Regulating cellular oxygen sensing by hydroxylation. Cardiovasc Res 71: 642-651, 2006.

24. Bruegge K, Jelkmann W and Metzen E: Hydroxylation of hypoxia-inducible transcription factors and chemical compounds targeting the HIF-alpha hydroxylases. Curr Med Chem 14 $1853-1862,2007$.

25. Frede S, Stockmann C, Freitag P and Fandrey J: Bacterial lipopolysaccharide induces HIF-1 activation in human monocytes via p44/42 MAPK and NF-kappaB. Biochem J 396: 517-527, 2006.

26. Ivan M, Kondo K, Yang H, Kim W, Valiando J, Ohh M, Salic A, Asara JM, Lane WS and Kaelin WG Jr: HIFalpha targeted for VHL-mediated destruction by proline hydroxylation: Implications for $\mathrm{O}_{2}$ sensing. Science 292: 464-468, 2001.

27. Jaakkola P, Mole DR, Tian YM, et al: Targeting of HIF-alpha to the von Hippel-Lindau ubiquitylation complex by $\mathrm{O}_{2}$-regulated prolyl hydroxylation. Science 292: 468-472, 2001.

28. Yu F, White SB, Zhao Q and Lee FS: HIF-lalpha binding to VHL is regulated by stimulus-sensitive proline hydroxylation. Proc Natl Acad Sci USA 98: 9630-9635, 2001.

29. Durán RV, MacKenzie ED, Boulahbel H, Frezza C, Heiserich L, Tardito S, Bussolati O, Rocha S, Hall MN and Gottlieb E: HIF-independent role of prolyl hydroxylases in the cellular response to amino acids. Oncogene 32: 4549-4556, 2013.

30. Moser SC, Bensaddek D, Ortmann B, Maure JF, Mudie S, Blow JJ, Lamond AI, Swedlow JR and Rocha S: PHD1 links cellcycle progression to oxygen sensing through hydroxylation of the centrosomal protein Cep192. Dev Cell 26: 381-392, 2013.

31. Luo W, Hu H, Chang R, Zhong J, Knabel M, O'Meally R, Cole RN, Pandey A and Semenza GL: Pyruvate kinase M2 is a PHD3-stimulated coactivator for hypoxia-inducible factor 1. Cell 145: 732-744, 2011.

32. Xie L, Pi X, Mishra A, Fong G, Peng J and Patterson C: PHD3-dependent hydroxylation of HCLK 2 promotes the DNA damage response. J Clin Invest 122: 2827-2836, 2012.

33. Pugh CW, Tan CC, Jones RW and Ratcliffe PJ: Functional analysis of an oxygen-regulated transcriptional enhancer lying 3 ' to the mouse erythropoietin gene. Proc Natl Acad Sci USA 88: 10553-10557, 1991

34. Semenza GL, Jiang BH, Leung SW, Passantino R, Concordet JP, Maire $\mathrm{P}$ and Giallongo A: Hypoxia response elements in the aldolase A, enolase 1, and lactate dehydrogenase A gene promoters contain essential binding sites for hypoxia-inducible factor 1. J Biol Chem 271: 32529-32537, 1996.
35. Schödel J, Oikonomopoulos S, Ragoussis J, Pugh CW, Ratcliffe PJ and Mole DR: High-resolution genome-wide mapping of HIF-binding sites by ChIP-seq. Blood 117: e207-e217, 2011.

36. Semenza GL: Regulation of cancer cell metabolism by hypoxiainducible factor 1. Semin Cancer Biol 19: 12-16, 2009.

37. Han YH, Xia L, Song LP, Zheng Y, Chen WL, Zhang L, Huang Y, Chen GQ and Wang LS: Comparative proteomic analysis of hypoxia-treated and untreated human leukemic U937 cells. Proteomics 6: 3262-3274, 2006.

38. Djidja MC, Chang J, Hadjiprocopis A, et al: Identification of hypoxia-regulated proteins using MALDI-mass spectrometry imaging combined with quantitative proteomics. J Proteome Res 13: 2297-2313, 2014

39. Gustafsson MV, Zheng X, Pereira T, Gradin K, Jin S, Lundkvist J, Ruas JL, Poellinger L, Lendahl U and Bondesson M: Hypoxia requires notch signaling to maintain the undifferentiated cell state. Dev Cell 9: 617-628, 2005.

40. Gordan JD, Bertout JA, Hu CJ, Diehl JA and Simon MC: HIF-2alpha promotes hypoxic cell proliferation by enhancing c-myc transcriptional activity. Cancer Cell 11: 335-347, 2007.

41. An WG, Kanekal M, Simon MC, Maltepe E, Blagosklonny MV and Neckers LM: Stabilization of wild-type p53 by hypoxiainducible factor 1alpha. Nature 392: 405-408, 1998.

42. Perkins ND: Integrating cell-signalling pathways with NF-kappaB and IKK function. Nat Rev Mol Cell Biol 8: 49-62, 2007.

43. No authors listed: Celebrating 25 years of NF- $\mathrm{B}$. Nat Immunol 12: 681,2011

44. Campbell KJ and Perkins ND: Regulation of NF-kappaB function. Biochem Soc Symp 73: 165-180, 2006.

45. Wong D, Teixeira A, Oikonomopoulos S, et al: Extensive characterization of NF- $\mathrm{B}$ binding uncovers non-canonical motifs and advances the interpretation of genetic functional traits. Genome Biol 12: R70, 2011

46. Gilmore TD: The Rel/NF-kappaB signal transduction pathway: Introduction. Oncogene 18: 6842-6844, 1999.

47. Chen F, Castranova V, Shi X and Demers LM: New insights into the role of nuclear factor-kappaB, a ubiquitous transcription factor in the initiation of diseases. Clin Chem 45: 7-17, 1999.

48. Bandarra DR and Rocha S: A tale of two transcription factors: NF- $\kappa \mathrm{B}$ and HIF crosstalk. OA Mol Cell Biol 1: 6, 2013.

49. Gilmore TD: Introduction to NF-kappaB: Players, pathways, perspectives. Oncogene 25: 6680-6684, 2006

50. Perkins ND and Gilmore TD: Good cop, bad cop: The different faces of NF-kappaB. Cell Death Differ 13: 759-772, 2006.

51. Aggarwal BB, Takada Y, Shishodia S, Gutierrez AM, Oommen OV, Ichikawa H, Baba Y and Kumar A: Nuclear transcription factor NF-kappa B: Role in biology and medicine. Indian J Exp Biol 42: 341-353, 2004.

52. Hackett PH and Roach RC: High-altitude illness. N Engl J Med 345: 107-114, 2001

53. Hartmann G, Tschöp M, Fischer R, Bidlingmaier C, Riepl R, Tschöp K, Hautmann H, Endres S and Toepfer M: High altitude increases circulating interleukin-6, interleukin-1 receptor antagonist and C-reactive protein. Cytokine 12: 246-252, 2000.

54. Kim HL, Cho YS, Choi H, Chun YS, Lee ZH and Park JW: Hypoxia-inducible factor 1alpha is deregulated by the serum of rats with adjuvant-induced arthritis. Biochem Biophys Res Commun 378: 123-128, 2009.

55. Boyd HK, Lappin TR and Bell AL: Evidence for impaired erythropoietin response to anaemia in rheumatoid disease. $\mathrm{Br} \mathrm{J}$ Rheumatol 30: 255-259, 1991.

56. Grenz A, Clambey E and Eltzschig HK: Hypoxia signaling during intestinal ischemia and inflammation. Curr Opin Crit Care 18: 178-185, 2012.

57. Eltzschig HK, Sitkovsky MV and Robson SC: Purinergic signaling during inflammation. N Engl J Med 367: 2322-2333, 2012.

58. Bandarra D, Biddlestone J, Mudie S, Muller HA and Rocha S: Hypoxia activates IKK-NF- $\kappa \mathrm{B}$ and the immune response in Drosophila melanogaster. Biosci Rep 34: 34, 2014.

59. Bandarra D, Biddlestone J, Mudie S, Muller HA and Rocha S: HIF- $1 \alpha$ restricts NF- $\kappa$ B dependent gene expression to control innate immunity signals. Dis Model Mech: Dec 15, 2014 (Epub ahead of print).

60. van Uden P, Kenneth NS, Webster R, Müller HA, Mudie S and Rocha S: Evolutionary conserved regulation of HIF-1 $\beta$ by NF-kB. PLoS Genet 7: e1001285, 2011.

61. van Uden P, Kenneth NS and Rocha S: Regulation of hypoxiainducible factor-1alpha by NF-kappaB. Biochem J 412: 477-484, 2008. 
62. XueX,Ramakrishnan S,Anderson E,Taylor M,ZimmermannEM, Spence JR, Huang S, Greenson JK and Shah YM: Endothelial PAS domain protein 1 activates the inflammatory response in the intestinal epithelium to promote colitis in mice. Gastroenterology 145: 831-841, 2013.

63. Karhausen J, Furuta GT, Tomaszewski JE, Johnson RS Colgan SP and Haase VH: Epithelial hypoxia-inducible factor-1 is protective in murine experimental colitis. J Clin Invest 114 1098-1106, 2004.

64. Sewell KL and Trentham DE: Pathogenesis of rheumatoid arthritis. Lancet 341: 283-286, 1993.

65. Al-Shukaili AK and Al-Jabri AA: Rheumatoid arthritis, cytokines and hypoxia. What is the link. Saudi Med J 27: 1642-1649, 2006.

66. Gaber T, Dziurla R, Tripmacher R, Burmester GR and Buttgereit F: Hypoxia inducible factor (HIF) in rheumatology: Low $\mathrm{O}_{2}$ ! See what HIF can do. Ann Rheum Dis 64: 971-980, 2005.

67. Hueber W, Kidd BA, Tomooka BH, et al: Antigen microarray profiling of autoantibodies in rheumatoid arthritis. Arthritis Rheum 52: 2645-2655, 2005.

68. van Baarsen LG, Wijbrandts CA, Rustenburg F, Cantaert T, van der Pouw Kraan TC, Baeten DL, Dijkmans BA, Tak PP and Verweij CL: Regulation of IFN response gene activity during infliximab treatment in rheumatoid arthritis is associated with clinical response to treatment. Arthritis Res Ther 12: R11, 2010.

69. van Wietmarschen HA, Dai W, van der Kooij AJ, et al: Characterization of rheumatoid arthritis subtypes using symptom profiles, clinical chemistry and metabolomics measurements. PLoS One 7: e44331, 2012.

70. Sweeney SE and Firestein GS: Signal transduction in rheumatoid arthritis. Curr Opin Rheumatol 16: 231-237, 2004.

71. Morel J and Berenbaum F: Signal transduction pathways: new targets for treating rheumatoid arthritis. Joint Bone Spine 71 503-510, 2004

72. Firestein GS and Manning AM: Signal transduction and transcription factors in rheumatic disease. Arthritis Rheum 42: 609-621, 1999

73. Benito MJ,Murphy E, Murphy EP, van den Berg WB, FitzGerald O and Bresnihan B: Increased synovial tissue NF-kappa B1 expression at sites adjacent to the cartilage-pannus junction in rheumatoid arthritis. Arthritis Rheum 50: 1781-1787, 2004.

74. Handel ML, McMorrow LB and Gravallese EM: Nuclear factorkappa B in rheumatoid synovium. Localization of p50 and p65. Arthritis Rheum 38: 1762-1770, 1995.

75. Müller-Ladner U, Pap T, Gay RE, Neidhart M and Gay S: Mechanisms of disease: The molecular and cellular basis of joint destruction in rheumatoid arthritis. Nat Clin Pract Rheumatol 1: 102-110, 2005

76. Simmonds RE and Foxwell BM: Signalling, inflammation and arthritis: NF-kappaB and its relevance to arthritis and inflammation. Rheumatology (Oxford) 47: 584-590, 2008

77. Westra J, Molema G and Kallenberg CG: Hypoxia-inducible factor-1 as regulator of angiogenesis in rheumatoid arthritis therapeutic implications. Curr Med Chem 17: 254-263, 2010.

78. Ryu JH, Chae CS, Kwak JS, et al: Hypoxia-inducible factor- $2 \alpha$ is an essential catabolic regulator of inflammatory rheumatoid arthritis. PLoS Biol 12: e1001881, 2014.

79. Hu F, Shi L, Mu R, et al: Hypoxia-inducible factor- $1 \alpha$ and interleukin 33 form a regulatory circuit to perpetuate the inflammation in rheumatoid arthritis. PLoS One 8: e72650, 2013.

80. Brouwer E, Gouw AS, Posthumus MD, van Leeuwen MA, Boerboom AL, Bijzet J, Bos R, Limburg PC, Kallenberg CG and Westra J: Hypoxia inducible factor-1-alpha (HIF-1alpha) is related to both angiogenesis and inflammation in rheumatoid arthritis. Clin Exp Rheumatol 27: 945-951, 2009.

81. Muz B, Khan MN, Kiriakidis S and Paleolog EM: Hypoxia. The role of hypoxia and HIF-dependent signalling events in rheumatoid arthritis. Arthritis Res Ther 11: 201, 2009.

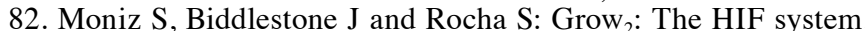
energy homeostasis and the cell cycle. Histol Histopathol 29: 589-600, 2014

83. Kenneth NS and Rocha S: Regulation of gene expression by hypoxia. Biochem J 414: 19-29, 2008.

84. Poonam P: The biology of oral tolerance and issues related to oral vaccine design. Curr Pharm Des 13: 2001-2007, 2007.

85. Podolsky DK: Inflammatory bowel disease. N Engl J Med 347 417-429, 2002

86. Cummins EP, Doherty GA and Taylor CT: Hydroxylases as therapeutic targets in inflammatory bowel disease. Lab Invest 93: 378-383, 2013

87. Abraham C and Cho JH: Inflammatory bowel disease. N Engl J Med 361: 2066-2078, 2009.
88. Giatromanolaki A, Sivridis E, Maltezos E, Papazoglou D, Simopoulos C, Gatter KC, Harris AL and Koukourakis MI: Hypoxia inducible factor lalpha and 2alpha overexpression in inflammatory bowel disease. J Clin Pathol 56: 209-213, 2003.

89. Danese S, Dejana E and Fiocchi C: Immune regulation by microvascular endothelial cells: Directing innate and adaptive immunity, coagulation, and inflammation. J Immunol 178: 6017-6022, 2007

90. Werth N, Beerlage C, Rosenberger C, et al: Activation of hypoxia inducible factor 1 is a general phenomenon in infections with human pathogens. PLoS One 5: e11576, 2010.

91. Cummins EP, Seeballuck F, Keely SJ, Mangan NE, Callanan JJ, Fallon PG and Taylor CT: The hydroxylase inhibitor dimethyloxalylglycine is protective in a murine model of colitis. Gastroenterology 134: 156-165, 2008.

92. Tambuwala MM, Cummins EP, Lenihan CR, et al: Loss of prolyl hydroxylase-1 protects against colitis through reduced epithelial cell apoptosis and increased barrier function. Gastroenterology 139: 2093-2101, 2010

93. Louis NA, Hamilton KE, Kong T and Colgan SP: HIF-dependent induction of apical CD55 coordinates epithelial clearance of neutrophils. FASEB J 19: 950-959, 2005.

94. Synnestredt K, Furuta GT, Comerford KM, Louis N, Karhausen J, Eltzschig HK, Hansen KR, Thompson LF and Colgan SP: Ecto-5'-nucleotidase (CD73) regulation by hypoxiainducible factor- 1 mediates permeability changes in intestinal epithelia. J Clin Invest 110: 993-1002, 2002.

95. Kong T, Westerman KA, Faigle M, Eltzschig HK and Colgan SP: HIF-dependent induction of adenosine $\mathrm{A} 2 \mathrm{~B}$ receptor in hypoxia. FASEB J 20: 2242-2250, 2006.

96. Louis NA, Hamilton KE, Canny G, Shekels LL, Ho SB and Colgan SP: Selective induction of mucin-3 by hypoxia in intestinal epithelia. J Cell Biochem 99: 1616-1627, 2006.

97. Furuta GT, Turner JR, Taylor CT, Hershberg RM, Comerford K, Narravula S, Podolsky DK and Colgan SP: Hypoxia-inducible factor 1-dependent induction of intestinal trefoil factor protects barrier function during hypoxia. J Exp Med 193: 1027-1034, 2001.

98. Comerford KM, Wallace TJ, Karhausen J, Louis NA Montalto MC and Colgan SP: Hypoxia-inducible factor-1dependent regulation of the multidrug resistance (MDR1) gene. Cancer Res 62: 3387-3394, 2002.

99. Neurath MF, Pettersson S, Meyer zum Büschenfelde KH and Strober W: Local administration of antisense phosphorothioate oligonucleotides to the p65 subunit of NF-kappa B abrogates established experimental colitis in mice. Nat Med 2: 998-1004, 1996.

100. Holtmann MH and Neurath MF: Differential TNF-signaling in chronic inflammatory disorders. Curr Mol Med 4: 439-444, 2004

101. Greten FR, Eckmann L, Greten TF, Park JM, Li ZW, Egan LJ, Kagnoff MF and Karin M: IKKbeta links inflammation and tumorigenesis in a mouse model of colitis-associated cancer. Cell 118: 285-296, 2004.

102. Pasparakis M: IKK/NF-kappaB signaling in intestinal epithelial cells controls immune homeostasis in the gut. Mucosal Immunol 1 (Suppl 1): S54-S57, 2008

103.Zaph C, Troy AE, Taylor BC, et al: Epithelial-cell-intrinsic IKK-beta expression regulates intestinal immune homeostasis. Nature 446: 552-556, 2007.

104. Hauser CJ, Locke RR, Kao HW, Patterson J and Zipser RD: Visceral surface oxygen tension in experimental colitis in the rabbit. J Lab Clin Med 112: 68-71, 1988.

105. Shah YM, Ito S, Morimura K, et al: Hypoxia-inducible factor augments experimental colitis through an MIF-dependent inflammatory signaling cascade. Gastroenterology 134: 2036-2048, 2048 e2031-2033, 2008.

106. Hara H and Saito T: CARD9 versus CARMA1 in innate and adaptive immunity. Trends Immunol 30: 234-242, 2009.

107. Yang H, Minamishima YA, Yan Q, Schlisio S, Ebert BL, Zhang X, Zhang L, Kim WY, Olumi AF and Kaelin WG Jr: pVHL acts as an adaptor to promote the inhibitory phosphorylation of the NF-kappaB agonist Card9 by CK2. Mol Cell 28: 15-27, 2007.

108. Rius J, Guma M, Schachtrup C, Akassoglou K, Zinkernagel AS, Nizet V, Johnson RS, Haddad GG and Karin M: NF-kappaB links innate immunity to the hypoxic response through transcriptional regulation of HIF-1alpha. Nature 453: 807-811, 2008.

109. Bracken CP, Whitelaw ML and Peet DJ: Activity of hypoxiainducible factor 2alpha is regulated by association with the NF-kappaB essential modulator. J Biol Chem 280: 14240-14251, 2005. 
110. O'Connell RM, Rao DS, Chaudhuri AA, Boldin MP Taganov KD, Nicoll J, Paquette RL and Baltimore D: Sustained expression of microRNA-155 in hematopoietic stem cells causes a myeloproliferative disorder. J Exp Med 205: 585-594, 2008.

111. Jemal A, Bray F, Center MM, Ferlay J, Ward E and Forman D: Global cancer statistics. CA Cancer J Clin 61: 69-90, 2011.

112. Hanahan D and Weinberg RA: Hallmarks of cancer: The next generation. Cell 144: 646-674, 2011.

113. Tsuzuki Y, Fukumura D, Oosthuyse B, Koike C, Carmeliet P and Jain RK: Vascular endothelial growth factor (VEGF) modulation by targeting hypoxia-inducible factor-1alpha--> hypoxia response element--> VEGF cascade differentially regulates vascular response and growth rate in tumors. Cancer Res 60: 6248-6252, 2000

114. Shay JE, Imtiyaz HZ, Sivanand S, et al: Inhibition of hypoxiainducible factors limits tumor progression in a mouse model of colorectal cancer. Carcinogenesis 35: 1067-1077, 2014.

115. Rawluszko-Wieczorek AA, Horbacka K, Krokowicz P, Misztal M and Jagodzinski PP: Prognostic potential of DNA methylation and transcript levels of HIF1A and EPAS1 in colorectal cancer. Mol Cancer Res: 12: 1112-1127, 2014.

116. Koshiji M, Kageyama Y, Pete EA, Horikawa I, Barrett JC and Huang LE: HIF-1alpha induces cell cycle arrest by functionally counteracting Myc. EMBO J 23: 1949-1956, 2004.

117. Sánchez-Puig N, Veprintsev DB and Fersht AR: Binding of natively unfolded HIF-1alpha ODD domain to p53. Mol Cell 17: $11-21,2005$

118. Ravi R, Mookerjee B, Bhujwalla ZM, Sutter CH, Artemov D, Zeng Q, Dillehay LE, Madan A, Semenza GL and Bedi A: Regulation of tumor angiogenesis by p53-induced degradation of hypoxia-inducible factor 1alpha. Genes Dev 14: 34-44, 2000.

119. Moeller BJ, Dreher MR, Rabbani ZN, Schroeder T, Cao Y, Li CY and Dewhirst MW: Pleiotropic effects of HIF-1 blockade on tumor radiosensitivity. Cancer Cell 8: 99-110, 2005.

120. Bertout JA, Majmundar AJ, Gordan JD, Lam JC, Ditsworth D, Keith B, Brown EJ, Nathanson KL and Simon MC: HIF2alpha inhibition promotes 553 pathway activity, tumor cell death, and radiation responses. Proc Natl Acad Sci USA 106: 14391-14396, 2009.

121. Volm M and Koomägi R: Hypoxia-inducible factor (HIF-1) and its relationship to apoptosis and proliferation in lung cancer. Anticancer Res 20: 1527-1533, 2000.

122. Evans AJ, Russell RC, Roche O, et al: VHL promotes E2 boxdependent E-cadherin transcription by HIF-mediated regulation of SIP1 and snail. Mol Cell Biol 27: 157-169, 2007.

123. Yang MH, Wu MZ, Chiou SH, Chen PM, Chang SY, Liu CJ, Teng SC and Wu KJ: Direct regulation of TWIST by HIF-1alpha promotes metastasis. Nat Cell Biol 10: 295-305, 2008.

124. Gort EH, van Haaften G, Verlaan I, et al: The TWIST1 oncogene is a direct target of hypoxia-inducible factor-2alpha. Oncogene 27: 1501-1510, 2008.

125. Thiery JP: Epithelial-mesenchymal transitions in tumour progression. Nat Rev Cancer 2: 442-454, 2002.

126. Sahlgren C, Gustafsson MV, Jin S, Poellinger L and Lendahl U: Notch signaling mediates hypoxia-induced tumor cell migration and invasion. Proc Natl Acad Sci USA 105: 6392-6397, 2008.

127. Lakatos PL and Lakatos L: Risk for colorectal cancer in ulcerative colitis: Changes, causes and management strategies. World J Gastroenterol 14: 3937-3947, 2008.

128. Munkholm P: Review article: The incidence and prevalence of colorectal cancer in inflammatory bowel disease. Aliment Pharmacol Ther 18 (Suppl 2): 1-5, 2003.

129. Fernández-Majada V, Aguilera C, Villanueva A, et al: Nuclear IKK activity leads to dysregulated notch-dependent gene expression in colorectal cancer. Proc Natl Acad Sci USA 104:276-281, 2007.

130. Seril DN, Liao J, Yang GY and Yang CS: Oxidative stress and ulcerative colitis-associated carcinogenesis: Studies in humans and animal models. Carcinogenesis 24: 353-362, 2003.

131. Sangha S, Yao M and Wolfe MM: Non-steroidal anti-inflammatory drugs and colorectal cancer prevention. Postgrad Med J 81: 223-227, 2005.

132. Hoffmeister M, Chang-Claude J and Brenner H: Do older adults using NSAIDs have a reduced risk of colorectal cancer. Drugs Aging 23: 513-523, 2006.

133. Becker C, Fantini MC, Schramm C, et al: TGF-beta suppresses tumor progression in colon cancer by inhibition of IL- 6 transsignaling. Immunity 21: 491-501, 2004.

134. Greten FR, Arkan MC, Bollrath J, et al: NF-kappaB is a negative regulator of IL-1beta secretion as revealed by genetic and pharmacological inhibition of IKKbeta. Cell 130: 918-931, 2007.
135. Karin M, Cao Y, Greten FR and Li ZW: NF-kappaB in cancer: From innocent bystander to major culprit. Nat Rev Cancer 2: 301-310, 2002.

136. Richmond A: Nf-kappa B, chemokine gene transcription and tumour growth. Nat Rev Immunol 2: 664-674, 2002.

137. Hanahan D and Weinberg RA: The hallmarks of cancer. Cell 100: 57-70, 2000.

138. Schulze-Bergkamen H and Krammer PH: Apoptosis in cancer-implications for therapy. Semin Oncol 31: 90-119, 2004.

139. Kucharczak J, Simmons MJ, Fan Y and Gélinas C: To be, or not to be: NF-kappaB is the answer - role of Rel/NF-kappaB in the regulation of apoptosis. Oncogene 22: 8961-8982, 2003.

140. Luo JL, Kamata H and Karin M: IKK/NF-kappaB signaling: Balancing life and death - a new approach to cancer therapy. J Clin Invest 115: 2625-2632, 2005

141. Cornejo MG, Boggon TJ and Mercher T: JAK3: A two-faced player in hematological disorders. Int J Biochem Cell Biol 41: 2376-2379, 2009.

142. Lin Q, Lai R, Chirieac LR, et al: Constitutive activation of JAK3/STAT3 in colon carcinoma tumors and cell lines: Inhibition of JAK3/STAT3 signaling induces apoptosis and cell cycle arrest of colon carcinoma cells. Am J Pathol 167: 969-980, 2005.

143. Tsareva SA, Moriggl R, Corvinus FM, Wiederanders B, Schütz A, Kovacic B and Friedrich K: Signal transducer and activator of transcription 3 activation promotes invasive growth of colon carcinomas through matrix metalloproteinase induction. Neoplasia 9: 279-291, 2007.

144. Guttridge DC, Albanese C, Reuther JY, Pestell RG and Baldwin AS Jr: NF-kappaB controls cell growth and differentiation through transcriptional regulation of cyclin D1. Mol Cell Biol 19: 5785-5799, 1999.

145. Chen C, Edelstein LC and Gélinas C: The Rel/NF-kappaB family directly activates expression of the apoptosis inhibitor Bcl-x(L). Mol Cell Biol 20: 2687-2695, 2000.

146. Baldwin AS: Control of oncogenesis and cancer therapy resistance by the transcription factor NF-kappaB. J Clin Invest 107: 241-246, 2001.

147. Choo MK, Sakurai H, Kim DH and Saiki I: A ginseng saponin metabolite suppresses tumor necrosis factor- $\alpha$-promoted metastasis by suppressing nuclear factor- $\mathrm{\kappa B}$ signaling in murine colon cancer cells. Oncol Rep 19: 595-600, 2008

148. Thomasova D, Mulay SR, Bruns H and Anders HJ: p53-independent roles of MDM2 in NF- $\mathrm{NB}$ signaling: Implications for cancer therapy, wound healing, and autoimmune diseases. Neoplasia 14: 1097-1101, 2012.

149. Puvvada SD, Funkhouser WK, Greene K, Deal A, Chu H, Baldwin AS, Tepper JE and O'Neil BH: NF- $\kappa$ B and Bcl-3 activation are prognostic in metastatic colorectal cancer. Oncology 78: 181-188, 2010.

150. Kwon HC, Kim SH, Oh SY, et al: Clinicopathological significance of nuclear factor-kappa B, HIF-1 alpha, and vascular endothelial growth factor expression in stage III colorectal cancer. Cancer Sci 101: 1557-1561, 2010.

151. Wu Y and Zhou BP: TNF-alpha/NF-kappaB/Snail pathway in cancer cell migration and invasion. Br J Cancer 102: 639-644, 2010.

152. Schwitalla S, ZieglerPK, Horst D, et al: Loss of $\mathrm{p} 53$ in enterocytes generates an inflammatory microenvironment enabling invasion and lymph node metastasis of carcinogen-induced colorectal tumors. Cancer Cell 23: 93-106, 2013.

153. Terzic J, Grivennikov S, Karin E and Karin M: Inflammation and colon cancer. Gastroenterology 138: 2101-2114 e2105, 2010

154. Newton IP, Kenneth NS, Appleton PL, Näthke I and Rocha S: Adenomatous polyposis coli and hypoxia-inducible factor-1 1 alpha\} have an antagonistic connection. Mol Biol Cell 21: 3630-3638, 2010

155. Bienz $\mathrm{M}$ and Clevers $\mathrm{H}$ : Linking colorectal cancer to Wnt signaling. Cell 103: 311-320, 2000.

156. McCartney BM and Näthke IS: Cell regulation by the Apc protein Apc as master regulator of epithelia. Curr Opin Cell Biol 20: 186-193, 2008.

157. Wen D, Zhang N, Shan B and Wang S: Helicobacter pylori infection may be implicated in the topography and geographic variation of upper gastrointestinal cancers in the Taihang Mountain high-risk region in northern China. Helicobacter 15: 416-421, 2010.

158. Krüger B, Krick S, Dhillon N, et al: Donor Toll-like receptor 4 contributes to ischemia and reperfusion injury following human kidney transplantation. Proc Natl Acad Sci USA 106: 3390-3395, 2009. 